\title{
LingTera
}

Volume 2 - Nomor 2, Oktober 2015, (208 - 221)

Available online at LingTera Website: http://journal.uny.ac.id/index.php/ljtp

\section{PENGEMBANGAN MEDIA PEMBELAJARAN BAHASA INGGRIS BERBASIS KOMPUTER UNTUK KETERAMPILAN MENYIMAK BAGI SISWA SMA KELAS X}

\author{
Septin Choirunnisa ${ }^{1)}$, Haryadi ${ }^{2)}$ \\ Politeknik Seni Yogyakarta ${ }^{1)}$, Universitas Negeri Yogyakarta ${ }^{2)}$ \\ septin3988@gmail.com ${ }^{1)}$, prof_haryadi@yahoo.co.id ${ }^{2)}$
}

\begin{abstract}
Abstrak
Tujuan penelitian ini adalah: (1) mengembangkan media pembelajaran bahasa Inggris berbasis komputer untuk keterampilan menyimak yang sesuai bagi siswa SMA kelas X dan (2) mengukur kualitas media pembelajaran hasil pengembangan tersebut ditinjau dari aspek materi, pembelajaran, dan media. Penelitian ini merupakan penelitian dan pengembangan (R\&D) dengan mengadaptasi model dan prosedur pengembangan dari Borg \& Gall, desain pembelajaran dari Dick \& Carey dan prosedur pengembangan software dari Criswell. Hasil penelitian menunjukkan bahwa kualitas media pembelajaran ditinjau dari aspek materi dinilai baik dengan rata-rata skor sebesar 4,20 ditinjau dari aspek pembelajaran dinilai sangat baik dengan rata-rata skor sebesar 4,28; dan ditinjau dari aspek media dinilai baik dengan rata-rata skor 4,10. Secara keseluruhan, kualitas media pembelajaran yang dikembangkan dinilai baik dengan rata-rata skor sebesar 4,19.
\end{abstract}

Kata kunci: media pembelajaran bahasa Inggris berbasis komputer, listening

\section{DEVELOPING COMPUTER-BASED ENGLISH INSTRUCTIONAL MEDIA FOR LISTENING SKILL AT YEAR-10 OF SENIOR HIGH SCHOOL}

\begin{abstract}
This study aims: (1) to develop computer-based English instructional media for listening skill appropriate for at year-10 students of senior high school and (2) to measure the quality of the developed instructional media in terms of the content, instructional and media aspects.This study was categorized as research and development $(R \& D)$. The procedure and the model of $R \& D$ cycle used in this study was adapted from Borg \& Gall, the instructional design from Dick \& Carey and software development procedure from Criswell. The result of the study shows that the quality of instructional media for in terms of the content aspect, it is categorized good with the mean score of 4.20; in terms of the instructional aspect, it is categorized very good with the mean score of 4.28; and in terms of the media aspect, it is categorized good with the mean score of 4.10. In terms of those three aspetcs, the developed instructional media are categorized good with the mean score of 4.19.
\end{abstract}

Keywords: computer-based English instructional media, listening. 


\section{PENDAHULUAN}

Pembelajaran bahasa Inggris di SMA/MA meliputi empat keterampilan berbahasa yaitu menyimak (listening), berbicara (speaking), membaca (reading), dan menulis (writing). Keempat keterampilan tersebut saling berintegrasi satu sama lain dalam proses pembelajaran bahasa Inggris dan merupakan keterampilan berbahasa yang harus dikuasai dalam pembelajaran bahasa Inggris.

Penelitian ini akan mengangkat permasalahan pada satu keterampilan berbahasa yaitu keterampilan menyimak. Brown (2001, p.247) mengungkapkan bahwa "In classrooms, students always do more listening than speaking. Listening competence is universally "larger" than speaking competence". Yang artinya bahwa siswa lebih sering melakukan kegiatan menyimak daripada berbicara di dalam kelas dan kemampuan menyimak lebih diutamakan daripada kemampuan berbicara.

Mengingat pentingnya keterampilan menyimak bagi siswa SMA/MA, maka guru harus mampu menyampaikan pembelajaran menyimak dengan model dan media pembelajaran yang tepat agar tujuan pembelajaran dapat tercapai secara optimal. Namun pada kenyataanya, pembelajaran menyimak di sekolah tidak mendapatkan porsi yang cukup secara kualitas maupun kuantitas, sehingga menyebabkan kemampuan menyimak siswa menjadi rendah. Menyimak dianggap oleh siswa sebagai keterampilan yang sulit untuk dikuasai dan dirasa kurang menarik.

Hal ini tidak hanya disebabkan dari faktor guru namun juga bisa disebabkan oleh media yang digunakan pada saat pembelajaran. Media dapat membantu guru agar lebih mudah dalam penyampaian materi.

Salah satu media yang dapat dapat menunjang proses pembelajaran bahasa adalah media berbasis komputer. Menurut Newby, et al. (2011, p.51) komputer dapat berperan sebagai guru dan asisten. Peran komputer sebagai guru adalah komputer dapat menyediakan materi-materi, mengevaluasi respon siswa dan memberikan feedback pada siswa. Komputer menjadi sangat interaktif, individual dan sangat toleran. Sedangkan peran komputer sebagai asisten adalah komputer dapat berfungsi sebagai alat bantu guru atau siswa untuk melakukan berbagai aktifitas salah satunya membuat materi multimedia.

Penggunaan media berbasis komputer dalam pembelajaran, memungkinkan siswa untuk mempelajari materi lebih lengkap dan rinci, serta dapat mengingat informasi tersebut lebih mendalam sehingga akan lebih lama tersimpan di otak. Hal ini sesuai dengan apa yang diungkapkan Dwyer (Pujiriyanto, 2005, p.6) yang menyatakan bahwa manusia pada umumnya mengingat $10 \%$ dari apa yang pernah dibaca, $20 \%$ dari apa yang pernah di dengar, 30\& dari apa yang dilihat, $50 \%$ dari apa yang pernah dilihat dan didengar, $70 \%$, dari apa yang pernah diperbincangkan dan $90 \%$ dari apa yang pernah dilakukannya.

Sejalan dengan Dwyer, Dale (Asyad, 2010, p.11) menjelaskan tentang pengalaman belajar siswa yang disebut dengan Dale's Cone of Experience (Kerucut Pengalaman Dale) sebagaimana tampak pada Gambar 1 berikut:

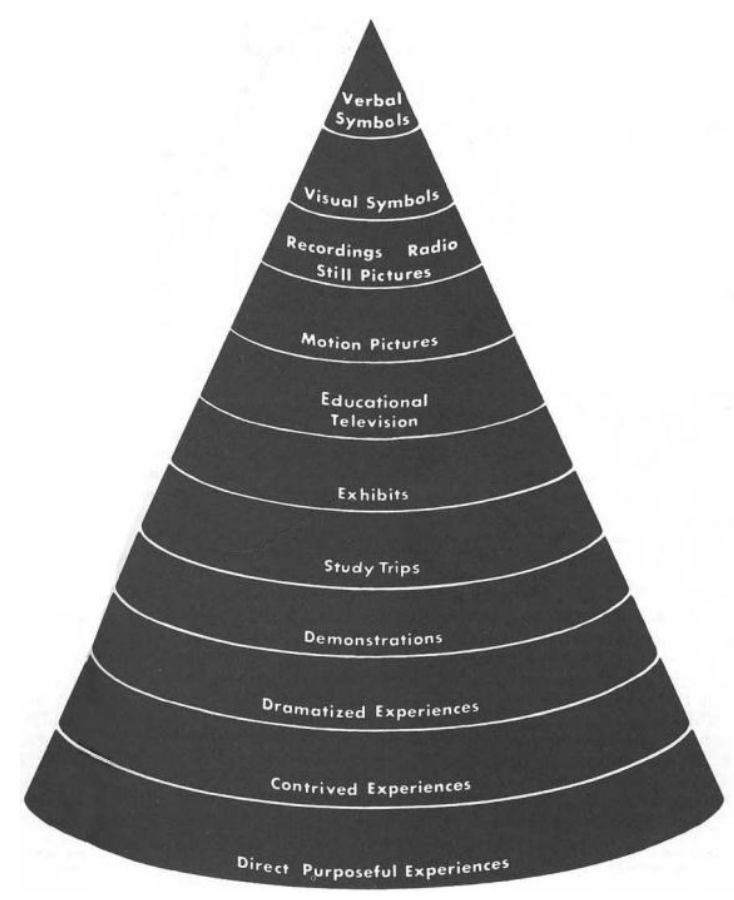

Gambar 1. Kerucut Pengalaman Edgar Gale

Berdasarkan Gambar 1, Dale menjelaskan bahwa hasil pengalaman belajar siswa diperoleh melalui pengalaman langsung (kongkret) kemudian melalui benda tiruan, hingga sampai pada lambang verbal (abstrak). Semakin ke atas di puncak kerucut, maka semakin abstrak media penyampaian pesan itu. Pengalaman langsung (direct purposeful experience) akan memberikan kesan paling bermakna pada siswa karena melibatkan indra penglihatan, pendengaran, perasaan, penciuman, dan peraba. Melalui media pembelajaran berbasis komputer ini, siswa tidak hanya mendengar atau melihat saja, tetapi juga bisa mengerjakan latihan maupun soal-soal yang diberikan. Sehingga pada akhirnya, siswa akan 
mudah memahami materi yang disajikan dalam media pembelajaran. Dengan demikian, dapat disimpulkan bahwa media pembelajaran berbasis komputer memegang peranan yang penting dalam proses pembelajaran.

Penggunaan media berbasis komputer juga bertujuan untuk meningkatkan efisiensi dan efektivitas pembelajaran. Proses pembelajaran dapat disampaikan pada waktu yang bersamaan atau pada waktu yang berbeda. Selain itu, penggunaan media pembelajaran ini juga dapat meningkatkan motivasi siswa sekaligus meningkatkan kualitas pembelajaran. Hal ini sejalan dengan pernyataan Arsyad (2010, p.55) yang menyatakan bahwa "Komputer memiliki kemampuan untuk merangsang siswa mengerjakan latihan dan melakukan simulasi karena tersedianya animasi, grafik, warna, dan musik yang dapat menambah realisme".

Penggunaan media pembelajaran berbasis komputer memiliki beberapa manfaat. Menurut Lee \& Owens $(2004$, p.60), manfaat dari penggunaan media berbasis komputer adalah: (1) penyampaian yang konsisten, (2) mengakomodasi waktu individu, (3) menjangkau kemampuan multisensorik, (4) pengoperasian dapat dikontrol siswa, (5) besarnya peran dan interaksi siswa, (6) menyesuaikan kemapuan siswa, (7) tes yang konsisten dan terekam, (8) pengulangan yang tidak terbatas, (9) pembelajaran yang lebih melalui peresentasi dan contoh pada konsep yang sama.

Namun demikian, media pembelajaran bahasa Inggris berbasis komputer masih jarang digunakan di sekolah. Hal ini disebabkan karena belum semua guru bahasa Inggris memiliki kemampuan dan kemauan untuk membuat dan menggunakan media tersebut. Media pembelajaran berbasis komputer dirasakan sukar untuk dibuat dan memakan banyak waktu. Disamping itu, software media pembelajaran bahasa Inggris berbasis komputer terutama untuk keterampilan menyimak masih jarang tersedia di pasaran. Hal ini menyebabkan pembelajaran menyimak di sekolah hanya dilaksanakan dengan menggunakan media seadanya.

Dari hasil observasi pendahuluan, diketahui bahwa sebagian besar media pembelajaran bahasa Inggris yang tersedia di sekolah berbentuk kaset. Guru memutar kaset menggunakan radiotape. Hal ini menjadikan siswa merasa bosan, kurang tertarik, dan daya tangkap menyimak siswa tidak dapat bertahan lama. Media kaset juga bersifat linear dan tidak interaktif, sehingga terkesan monoton dan kurang menarik ketika dipakai dalam pembelajaran. Hal ini menjadi sangat ironis menilik bahwa perkembangan zaman dan teknologi saat ini, dimana sarana prasarana penunjang proses pembelajaran sudah sangat variatif dan modern. Komputer merupakan salah satu produk dari perkembangan teknologi yang sudah selayaknya untuk dimanfaatkan menjadi salah satu sarana penunjang proses pembelajaran.

Ketersediaan komputer disekolah sudah di dukung oleh program pemerintah, baik dari dana BOS, program KUS (Komputer untuk sekolah), maupun program-program lain. Sehingga dapat disimpulkan bahwa hampir setiap unit satuan pendidikan/sekolah telah memiliki komputer. Ketersediaan komputer di sekolah, seharusnya dapat dimanfaatkan secara maksimal untuk mengatasi masalah-masalah pembelajaran.

Berpijak pada masalah yang dihadapi siswa dan guru tentang terbatasnya media pembelajaran menyimak dan penggunaan komputer yang belum maksimal, maka peneliti bermaksud mengembangkan sebuah media pembelajaan $\mathrm{Ba}-$ hasa Inggris berbasis komputer untuk keterampilan menyimak bagi siswa SMA kelas $\mathrm{X}$, sebagai salah satu upaya untuk meningkatkan kualitas pembelajaran Bahasa Inggris dan mengupayakan terciptanya SDM yang dapat mengikuti perkembangan teknologi sekaligus sebagai langkah nyata untuk mencapai tujuan pendidikan nasional.

\section{METODE}

\section{Model Pengembangan}

Penelitian ini merupakan penelitian dan pengembangan (research and development) yang digunakan untuk menghasilkan produk tertentu dan menguji validitas produk pembelajaran yang dihasilkan. Produk yang dikembangkan pada penelitian ini berupa media pembelajaran bahasa Inggris berbasis komputer untuk keterampilan menyimak bagi siswa SMA/ MA kelas. Model dalam pengembangan ini diadaptasi dari Model Borg and Gall (1983, p.775), desain pembelajaran dari Dick \& Carey (2005, pp.6-8), dan langkah-langkah pengembangan software berbasis komputer menurut Criswell (1989, pp.50-81) dalam Winarno, et al. (2009, pp.20-21).

\section{Prosedur Pengembangan}

Prosedur peneltian ini melalui empat tahap, yaitu: (1) penelitian pendahuluan, (2) perencanaan pengembangan media, (3) produksi 
media, dan (4) evaluasi media dan revisi. Dalam bagan sederhana, model pengembagan yang digunakan dalam penelitian dan pengembangan ini dapat digambarkan seperti pada Gambar 2 berikut:

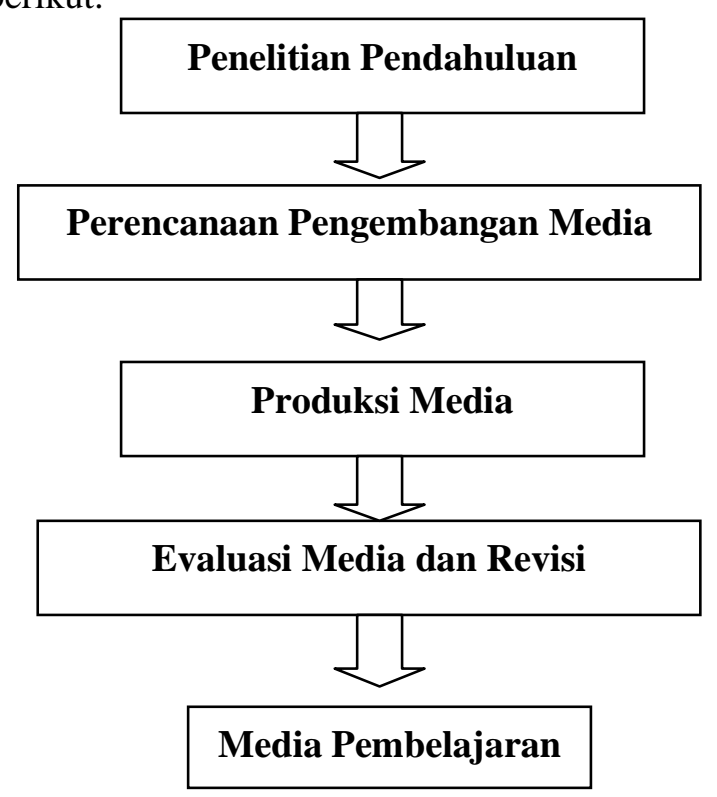

Gambar 2. Model Pengembangan Media Pembelajaran Berbasis Komputer Diaptasi dari model Borg \& Gall (1983), Dick \& Carey (2005) dan Criswell (1989)

\section{Uji Coba Produk}

Uji coba produk dimaksudkan untuk mengumpulkan data tentang kualitas produk baik dari aspek pembelajaran, materi maupun media. Data-data uji coba produk diperoleh dari hasil validasi ahli materi dan pembelajaran, validasi ahli media, dan hasil uji coba media pada siswa SMA/MA kelas X melalui uji coba satusatu, uji coba kelompok kecil, dan uji coba lapangan. Hasil dari data-data tersebut, akan diperoleh informasi mengenai kelemahan, kekurangan maupun keunggulan dari produk tersebut.

\section{Subjek Uji Coba}

Subjek pada penelitian ini adalah siswa kelas X MA Sunan Pandanaran Ngaglik Sleman pada tahun pelajaran 2012/2013. Jumlah subjek seluruhnya ada 45 siswa, dengan rincian 3 siswa untuk uji coba satu-satu, 12 siswa untuk uji coba kelompok kecil, dan 30 siswa untuk uji coba lapangan.

Untuk validasi, dipilih dua orang ahli yaitu satu ahli materi dan pembelajaran dan satu ahli media. Ahli materi dan pembelajaran dalam penelitian ini adalah Bp.Nurhidayanto, M.Pd, seorang dosen Pendidikan Bahasa Inggris dari FBS UNY. Ahli media adalah Bp. Herman Dwi Surjono, Ph.D., seorang dosen Teknologi Pembelajaran PPs UNY.

\section{Data, Intrumen, dan Teknik Pengumpulan Data}

Data yang digunakan dalam penelitian ini adalah data kualitatif dan data kuantitatif. Data kualitatif diperoleh dari tanggapan mengenai aspek pembelajaran, materi, dan media dari berbagai sumber, yaitu ahli materi dan pembelajaran, ahli media dan siswa melalui kuesioner, dan pedoman wawancara. Data kuantitatif terdiri dari dua jenis data. Data pertama diperoleh melalui penilaian yang dilakukan oleh ahli materi dan pembelajaran dan ahli media melalui lembar validasi serta dari siswa melalui kuesioner. Data kuantitatif yang kedua adalah nilai siswa pada saat pretest dan posttest.

\section{Teknik Analisis Data}

Data yang diperoleh dari ahli materi dan pembelajaran, ahli media dan siswa dikumpulkan melalui kuesioner dan dianalisis dengan statistik deskriptif dengan teknik persentase dan kategorisasi. Data-data dan saran-saran yang diperoleh tersebut, dianalisis dan disimpulkan untuk memperbaiki produk media pembelajaran.

\section{HASIL DAN PEMBAHASAN}

Produk pengembangan media pembelajaran berbasis komputer untuk keterampilan menyimak bagi siswa kelas $\mathrm{X}$ telah selesai dikembangkan melalui beberapa rangkaian kegiatan penelitian dan pengembangan. Pengembangan media pembelajaran ini melalui empat tahap yaitu empat tahap yaitu penelitian pendahuluan, perencanaan pengembangan media, produksi media, dan evaluasi media serta revisi.

Tahap pertama adalah penelitian pendahuluan yang dilakukan dengan cara melakukan analisis kebutuhan dan studi pustaka. Analisis kebutuhan dilakukan melalui studi cara observasi, dan penyebaran angket. Sedangkan studi pustaka dilakukan dengan cara studi kurikulum, silabus mata pelajaran Bahasa Inggris, bukubuku teks yang berkaitan dengan materi dalam produk, buku-buku pelajaran bahasa Inggris dan jurnal atau laporan hasil penelitian tentang penggunaan media pembelajaran berbasis komputer.

Berdasarkan analisis kebutuhan yang didapatkan melalui observasi dan penyebaran angket kepada guru dan siswa, diperoleh data sebagai berikut: (1) Guru merasa kesulitan 
dalam menyampaikan materi bahasa Inggris kepada siswa karena kurangnya media pembelajaran. Guru juga kesulitan mendapatkan media pembelajaran berbasis komputer seperti CD pembelajaran. Sehingga media yang digunakan guru masih berupa media konvensional seperti LKS, buku paket dan rekaman-rekaman suara; (2) Guru belum memanfaatkan fasilitas belajar di sekolah yang berupa laboratorium komputer dan laboratorium bahasa secara optimal untuk pembelajaran bahasa Inggris; (3) Guru menyatakan bahwa keterampilan berbahasa dalam pembelajaran bahada Inggris yang paling sulit dikuasai oleh siswa adalah keterampilan menyimak dan media pembelajaran yang paling sulit didapatkan adalah media pembelajaran bahasa Inggris untuk keterampilan menyimak; (4) Siswa menyatakan bahwa keterampilan menyimak merupakan keterampilan penting untuk dikuasai namun siswa merasa bahwa keterampilan tersebut sulit untuk dikuasai; (5) Siswa menginginkan penggunaan media pembelajaran berbasis komputer untuk keterampilan menyimak karena selama ini media yang digunakan untuk pembelajaran menyimak masih berupa media konvensional seperti rekaman-rekaman suara yang diputar dengan tape recorder atau laptop; (6) Berdasarkan kegiatan studi pustaka yang dilakukan, diperoleh data sebagai berikut: (7) Standar kompetensi mata pelajaran bahasa Inggris bagi siswa kelas X SMA pada keterampilan menyimak adalah memahami makna dalam percakapan transaksional dan interpersonal dalam konteks kehidupan sehari-hari; (8) Penggunaan media pembelajaran berbasis komputer untuk pembelajaran bahasa Inggris memberikan dampak yang positif terhadap proses pembelajaran dan hasil belajar siswa.

Berdasarkan data-data hasil penelitian pendahuluan dapat disimpulkan bahwa keterampilan menyimak merupakan keterampilan yang penting untuk dikuasai dan penggunaan media pembelajaran berbasis komputer untuk keterampilan menyimak pada pembelajaran bahasa Inggris sangat diharapkan oleh guru maupun siswa.

Tahap kedua adalah perencanaan pengembangan. Tahap ini dilakukan dengan cara memilih standar kompetensi dan kompetensi dasar, merumuskan indikator pembelajaran, menetapkan materi pembelajaran, menyusun strategi pembelajaran, menetapkan sistem penilaian, menentukan program yang digunakan, membuat flowchart dan storyboard (alur cerita/skenario), dan mengumpulkan bahan. Standar Kompetensi dan kompetensi dasar yang dipilih adalah standar kompetensi dan kompetensi dasar mata pelajaran bahasa Inggris kelas $\mathrm{X}$ di semester satu. Penelitian ini akan mengembangkan media pembelajaran berbasis komputer untuk keterampilan menyimak yang mencakup satu Standar Kompetensi (SK) dan satu Kompetensi Dasar (KD) yaitu: Standar Kompetensi (SK): Memahami makna dalam percakapan transaksional dan interpersonal dalam konteks kehidupan sehari-hari dan Kompetensi Dasar (KD): Merespon makna yang terdapat dalam percakapan transaksional (to get things done) dan interpersonal (bersosialisasi) resmi dan tak resmi yang menggunakan ragam bahasa lisan sederhana secara akurat, lancar dan berterima dalam konteks kehidupan sehari-hari dan melibatkan tindak tutur: berkenalan, bertemu/berpisah, menyetujui ajakan/tawaran/undangan, menerima janji, dan membatalkan janji.

Selanjutnya, dilakukan perumusan indikator pembelajaran yang terdiri atas sembilan indikator dari 3 materi pembelajaran yang digunakan dalam media pembelajaran. Ketiga materi tersebut adalah: (1) greeting, introducing and parting, (2) making, accepting and declining invitation, dan (3) making and cancelling appointment.

Strategi pembelajaran yang digunakan adalah teori pembelajaran menurut Feez \& Joyce (2002, pp.27-31). Berdasarkan teori tersebut, tiap-tiap materi pembelajaran dibagi menjadi 3 tahapan yaitu Building the Context (Let's Build Our Knowledge), Modelling and Deconstructing The Text (Let's Learn It More) dan Joint Construction of Text (Let's Check Your Competence). Langkah selanjutnya adalah penetapan sistem penilaian dengan cara menyusun beberapa butir soal yang berkaitan dengan materi untuk dimasukan pada bagian evaluasi.

Langkah selanjutnya adalah menentukan program yang digunakan. Dalam pembuatan media pembelajaran ini, peneliti memilih program Adobe Flash CS4 dan program pendukung yaitu Adobe Photoshop CS6 dan Adobe Premiere CS3. Selanjutnya, peneliti membuat flowchart dan storyboard yang dijadikan sebagai panduan dalam membuat media pembelajaran. Setelah pembuatan storyboard dan flowchart, peneliti mengumpulkan bahan yang akan digunakan dalam media pembelajaran. Bahan yang dimaksud adalah semua jenis teks, gambar, suara dan video yang semuanya harus disimpan dalam bentuk file dan dikelompokkan dalam folder yang berbeda sesuai dengan jenis filenya. 
Contoh Flowchart yang digunakan pada pengembangan media pembelajaran ini tampak pada Gambar 3 berikut:

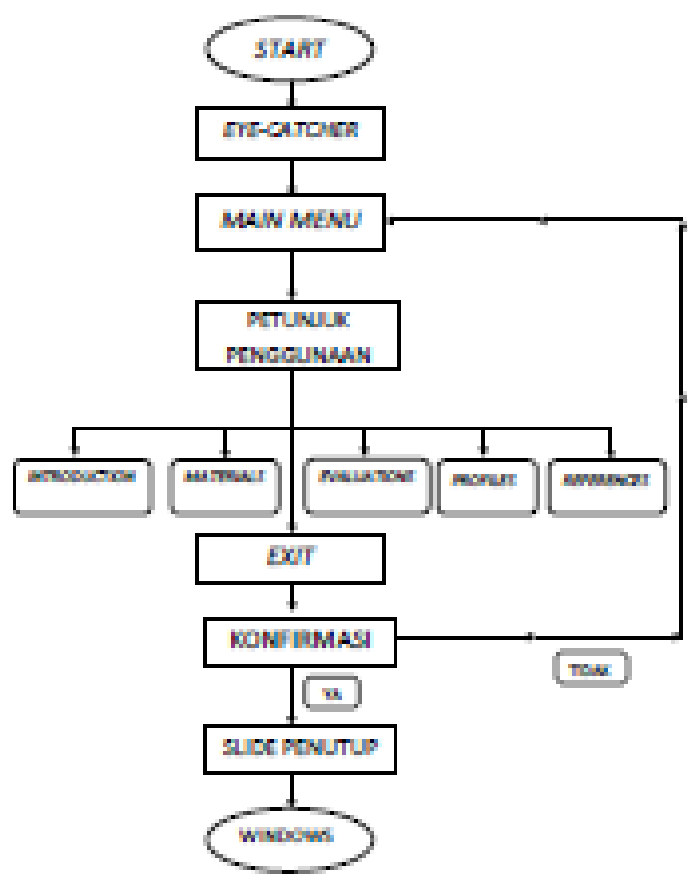

Gambar 3. Contoh Flowchart Media

Pembelajaran Bahasa Inggris Berbasis

Komputer untuk Keterampilan Menyimak bagi Siswa SMA Kelas X

Selain membuat flowchart, peneliti juga membuat storyboard sebagai acuan desain tampilan media yang dikembangkan, Dalam storyboard ini, peneliti menuangkan rencana tampilan per slide seperti teks, gambar, animasi, suara, dan tombol-tombol yang aktif. Berikut ini adalah contoh storyboard yang digunakan dalam pengembangan media pembelajaran ini sebagaimana tampak pada Gambar 4 berikut:

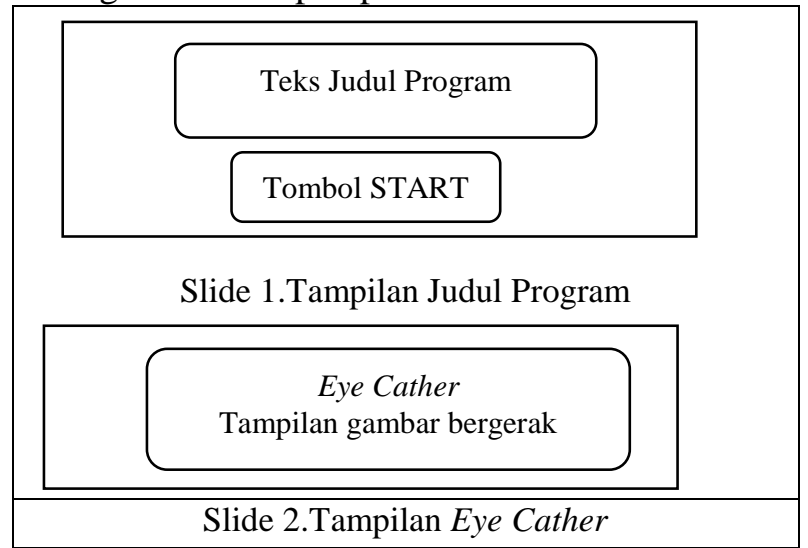

Gambar 4. Contoh Storyboard Media

Pembelajaran Bahasa Inggris Berbasis

Komputer untuk Keterampilan Menyimak bagi

Siswa SMA Kelas X
Tahap ketiga adalah produksi media/software. Tahap ini terdiri atas dua langkah yaitu membuat software pembelajaran dan mewujudkan software pembelajaran ke dalam bentuk CD. Pembuatan software pembelajaran adalah proses merangkai semua materi yang telah dipersiapkan menggunakan program Adobe Flash CS4. Adobe Flash CS4 adalah salah satu aplikasi pembuat animasi yang cukup memiliki berbagai fitur dan kemudahan sehingga Adobe Flash CS4 menjadi program animasi favorit dan cukup populer. Tampilan interface, fungsi dan pilihan palet yang beragam, serta kumpulan tool yang sangat lengkap sangat membantu dalam pembuatan media pembelajaran yang menarik. Dengan menggunakan Adobe Flash CS4, berbagai aplikasi animasi 2D dapat dibuat seperti membuat animasi kartun, animasi interaktif, game, company profile, presentasi, video clip, movie, web animasi, dan aplikasi animasi lainnya (Puspitosari, 2010, p.3).

Puspitosari (2010, pp.3-4) juga menyatakan keunggulan dari program Adobe Flash CS4 dibanding program lain yang sejenis antara lain: (1) dapat membuat tombol interaktif, (2) dapat membuat perubahan transparansi warna dalam movie, (3) dapat membuat animasi perubahan bentuk, (4) dapat membuat animasi transformasi 3D, (4) dapat membuat animasi dekorasi yang merupakan salah satu fitur terbaru, (5) dapat membuat animasi Bone, (6) dapat membuat animaasi pada suatu alur tertentu, (6) file dapat dikonversi dalam bentuk tipe: .swf, .html, .gif, .png, .exe, .mov.

Selain keunggulan-keunggulan tersebut, program Flash juga dapat mengimpor hampir semua gambar dan file-file audio sehingga dapat lebih hidup. Dengan melihat kemampuan flash yang handal dalam desain animasi tentunya akan sangat bermanfaat bagi para desainer maupun guru dalam rangka mengembangkan media pembelajaran berbasis komputer yang menarik bagi siswa. Hasil akhir dari media pembelajaran tersebut dapat disimpan ke dalam CD-ROM karena ukuran file flash tidak terlalu besar namun memiliki kualitas yang baik.

Langkah selanjutnya adalah mewujudkan software dalam bentuk CD. Penyimpanan dalam CD ini merujuk pada pernyataan Goh (Ward \& Renandya, 1998, p.79) menyatakan bahwa perkembangan teknologi khusunya komputer dapat memberikan fasilitas terhadap penggunaan materi autentik untuk pengajaran menyimak. Rekaman dari materi tersebut dapat disimpan di dalam Compact disks (CD). Menurut Goh, 
kualitas suara yang disimpan di CD lebih baik dari pada kualitas suara yang disimpan menggunakan kaset video. Selain itu, CD menyimpan lebih banyak rekaman suara dengan kualitas yang lebih bagus dibandingkan kaset. Selain itu penggunaan $\mathrm{CD}$ dengan menggunakan komputer memiliki banyak manfaat bagi siswa dalam mengembangkan kemampuan menyimak. Menurut Goh (Ward \& Renandya, 1998, p.82), ada empat manfaat penggunaan $\mathrm{CD}$ untuk pembelajaran menyimak, yaitu: $\mathrm{CD}$ bisa menyimpan banyak materi menyimak yang autentik, $C D$ berisi materi yang informatif dan menyenangkan bagi siswa, CD berisi materi menyimak yang dilengkapi dengan gambar, animasi, dan video, dan $\mathrm{CD}$ bisa memuat transkrip dari materi yang disajikan.

Secara garis besar media pembelajaran hasil pengembangan pada tahap ini berisi: (1) Tampilan Judul yang berisi judul, nama peneliti, NIM dan Universtias peneliti; (2) Slide pembukaan (eye cacther) berisi gambar bergerak yang bertujuan untuk menarik perhatian siswa; (3) Petunjuk penggunaan program yang menunjukkan kepada pengguna cara menjalankan program atau produk media yang dikembangkan; (4) Slide Menu Utama yang berisi tombol-tombol aktif yaitu:

Pendahuluan, memuat Standar Kompetensi (SK), Kompetensi Dasar (KD), dan indikator pembelajaran yang harus dicapai siswa setelah proses pembelajaran. Materi, terbagi menjadi beberapa bagian. Materi yang ditampilan dalam media pembelajaarn ini mencakup tiga materi yaitu greeting, introducing and parting, making, accepting and declining invitation, making and cancelling appointment. Dalam materi-materi tersebut disajikan video-video sebagai contoh materi teks transaksional dan interpersonal. Selain itu juga juga disajikan latihan soal interaktif dengan umpan balik (feedback) yang langsung diberikan saat siswa mengerjakan soal-soal latihan. Evaluasi, yang memuat soal-soal evaluasi yang dapat digunakan untuk mengukur kemampuan siswa dalam memahami materi yang disajikan. Identitas Pengembang, yang berisi tentang identitas diri pengembang, pembimbing, ahli materi dan pembelajaran dan ahli media yang terlibat dalam penelitian pengembangan ini. References, yang memuat sumber-sumber materi, gambar maupun video yang digunakan dalam media pembelajaran. Slide konfirmasi keluar yang berisi pernyataan apakah pengguna benar-benar ingin keluar dari program yang sedang dijalankan.
Slide ucapan terima kasih yang menampilkan ucapan terima kasih pada pihak-pihak yang terkait dalam pembuatan media pembelajaran. Dalam slide ini juga ditampilan program-program yang digunakan dalam pembuatan media ini.

Contoh tampilan media pembelajaran bahasa Inggris yang dikembangkan dalam penelitian ini tampak pada Gambar 5 sampai dengan Gambar 9 sebagai berikut:

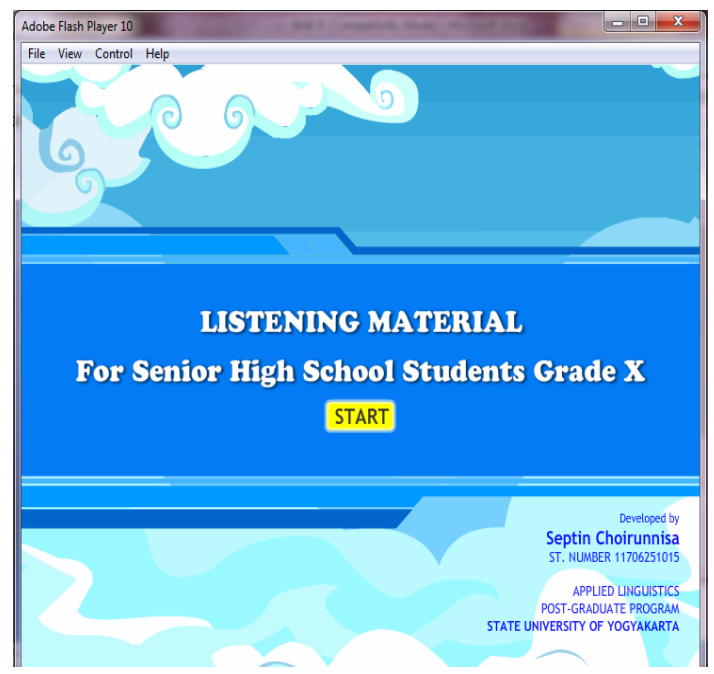

Gambar 5. Tampilan Slide Judul Program

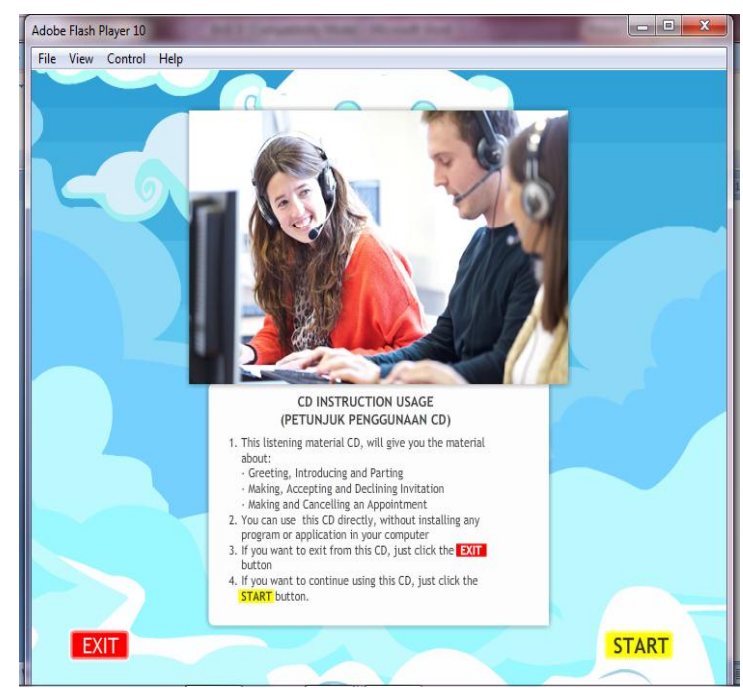

Gambar 6. Tampilan Slide Petunjuk Penggunaan 


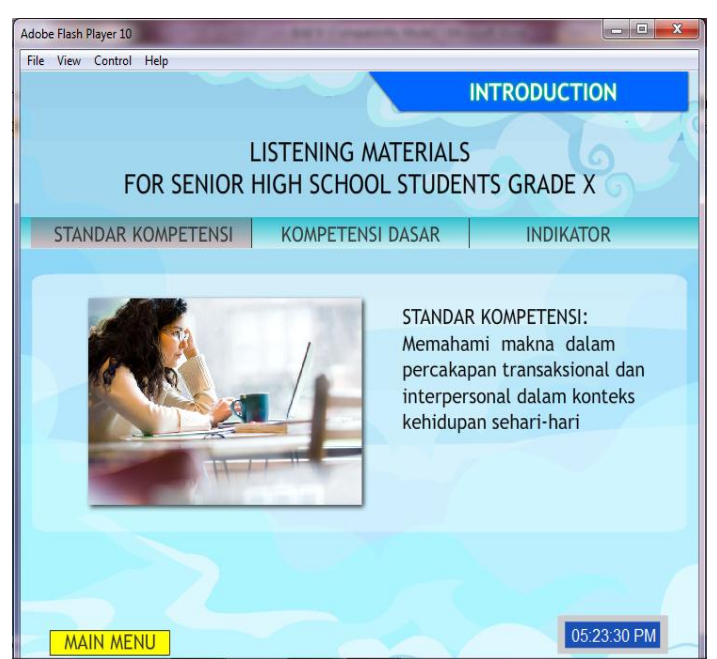

Gambar 7. Tampilan Slide Introduction

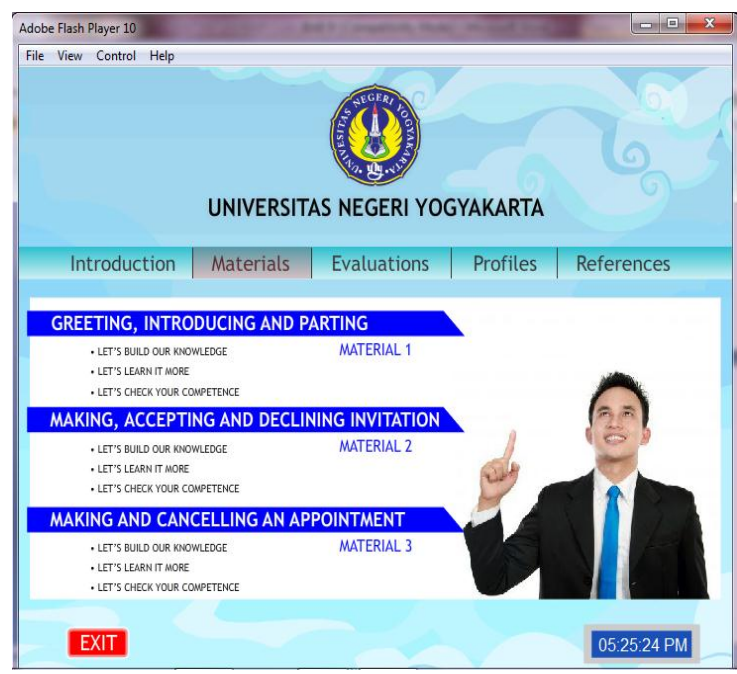

Gambar 8. Tampilan Slide Materials

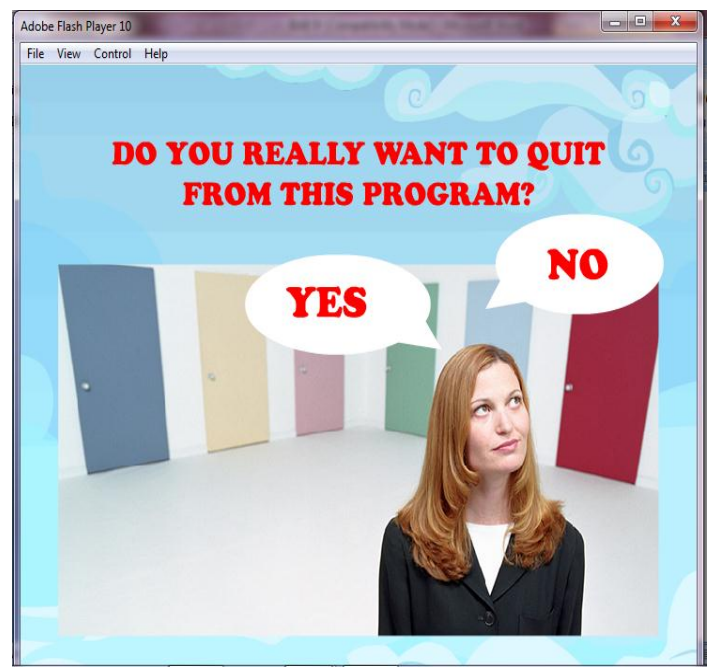

Gambar 9. Tampilan Slide Konfirmasi

Tahap terakhir adalah evaluasi dan revisi media. Tahap evaluasi dan revisi dilaksanakan dengan cara melakukan validasi ahli materi dan pembelajaran, ahli media, uji coba satu-satu, uji coba kelompok kecil dan uji coba lapangan. Di setiap akhir tahapan evaluasi dilakukan analisis data dan revisi produk berdasarkan data yang diperoleh. Produk media pembelajaran yang dikembangkan ini telah melalui serangkaian tahapan uji coba dan layak untuk dimanfaatkan dalam pembelajaran bahasa Inggris khusunya keterampilan menyimak. Media pembelajaran ini telah memiliki validitas materi atau kebenaran materi berdasarkan review ahli materi dan pembelajaran. Media ini juga telah memiliki kebenaran aspek media berdasarkan review ahli media.

Dalam memberikan penilaian, dalam kuesioner disediakan lima pilihan untuk memberikan tanggapan tentang media pembelajaran yang dikembangkan berdasarkan yaitu: sangat baik (5), baik (4), cukup baik (3), kurang baik (2), dan sangat kurang baik (1). Penilaian tersebut berdasarkan skala Likert (Situmorang, 2010, p.5). Misalnya siswa memberi tanggapan "sangat baik" pada butir pertanyaan, maka skor butir pertanyaan tersebut adalah " 5", demikian seterusnya. Skor yang diperoleh, dikonversikan menjadi nilai, pada skala 5, dengan acuan tabel yang dikutip dari Sukardjo (2006, pp.52-53). Penggunaan skala lima ini memudahkan dalam penafsiran hasil kualitas media yang dikembangkan.

Pada saat validasi aspek materi, ahli materi dan pembelajaran memberikan penilaian terhadap 12 indikator penilaian, yaitu: (1) kebenaran materi, (2) kedalaman materi, (3) kesesuaian materi dengan tingkat kesulitan siswa, (4) ketepatan urutan penyajian materi, (5) keterkinian atau aktualisasi materi, (6) pentingnya materi, (7) kemenarikan materi, (8) kemudahan memahami materi, (9) konsep yang diberikan dapat dipahami, 10) penggunaan bahasa dan tata bahasa, (11) kesesuaiann materi dengan soal dan (12) tingkat kesulitan butir soal. Pada aspek materi, rata-rata penilaian yang diperoleh adalah 4,42 dengan kategori "sangat baik". Butir 5, 6, 7, 10 dan 11 mendapat skor penilaian 5 sedangkan butir 1, 2, 3, 4, 8, 9 dan 12 mendapat skor penilaian 4 .

Berikut ini adalah persentase penilaian aspek materi oleh ahli materi dan pembelajaran, sebagaiman tampak pada Tabel 1. 
Tabel 1. Persentase Penilaian Aspek Materi oleh Ahli Materi dan Pembelajaran

\begin{tabular}{ccc}
\hline Kriteria & Frekuensi & \% \\
\hline Sangat Baik & 5 & $41,67 \%$ \\
Baik & 7 & $58,33 \%$ \\
Cukup Baik & 0 & $0 \%$ \\
Kurang Baik & 0 & $0 \%$ \\
Sangat Kurang Baik & 0 & $0 \%$ \\
Jumlah & $\mathbf{1 2}$ & $\mathbf{1 0 0 \%}$ \\
\hline
\end{tabular}

Berdasarkan Tabel 1, ahli materi dan pembelajaran memberikan penilaian dengan kriteria "Baik" pada tujuh pernyataan dan dengan kriteria "Sangat baik" pada lima pernyataan. Tidak ada pernyataan yang termasuk dalam katergori "cukup baik", "kurang baik" maupun "sangat kurang baik".

Sedangkan pada aspek pembelajaran, ahli materi dan pembelajaran memberikan penilaian tehadap 13 indikator penilaian yaitu: (1) kejelasan standar kompetensi, (2) kejelasan kompetensi dasar, (3) kejelasan indikator keberhasilan yang akan dicapai, (4) kejelasan petunjuk belajar, (5) kejelasan uraian materi, (6) keterkaitan anatara kompetensi dasar, indikator, materi dan evaluasi, (7) penyampaian materi menarik, (8) pemberian animasi, suara dan video sebagai bahan penarik perhatian siswa, (10) kegiatan belajar dapat memotivasi siswa, (11) pemberian soal latihan untuk pemahaman materi, (12), pemberian soal evaluasi untuk mengukur kemampuan siswa, dan (13) respon terhadap jawaban siswa. Rata-rata penilaian ahli materi dan pembelajaran terhadap aspek pembelajaran adalah 4,53 dan termasuk dalam kategori 'Sangat baik'. Pernyataan nomor 1, 2, 3, 5, 6, 11 dan 13 mendapat skor penilaian 5 dengan kategori "sangat baik" sedangkan pernyataan nomor $4,7,8,9,10$ dan 12 mendapat skor penilaian 4 yang termasuk dalam kategori "baik".

Persentase penilaian ahli materi dan pembelajaran pada aspek materi atau isi tampak pada Tabel 2 berikut ini:

Tabel 2. Persentase Penilaian Aspek Pembelajaran oleh Ahli Materi dan Pembelajaran

\begin{tabular}{ccc}
\hline Kriteria & Frekuensi & \% \\
\hline Sangat Baik & 7 & $53,85 \%$ \\
Baik & 6 & $46,15 \%$ \\
Cukup Baik & 0 & $0 \%$ \\
Kurang Baik & 0 & $0 \%$ \\
Sangat Kurang Baik & 0 & $0 \%$ \\
Jumlah & $\mathbf{1 2}$ & $\mathbf{1 0 0 \%}$ \\
\hline
\end{tabular}

Berdasarkan Tabel 2, ada tujuh pernyataan yang termasuk dalam kategori "sangat baik" dan ada enam pernyataan yang termasuk dalam kategori "baik". Tidak ada penilaian terhadap pernyataan yang termasuk dalam kategori "cukup baik", "kurang baik" maupun "sangat kurang baik".

Ahli media memberikan penilaian terhadap 21 indikator penilaian yaitu: (1) penggunaan jenis dan ukuran huruf, (2) pengaturan jarak, (3) keterbacaan teks, (4) tampilan gambar, (5) penempatan gambar, (6) tampilan video, (7) kejelasan suara/narasi, (8) desain slide, (9) tata letak, (10) tampilan button, (11) konsistensi penempatan button, (12) komposisi dan kombinasi penggunaan warna, (13) konsistensi penyajian, (14) kemudahan navigasi, (15) kemudahan memilih menu sajian, (16) kebebasan memilih menu sajian, (17) kemudahan dalam penggunaan media, (18) penanganan respon siswa, (19) kejelasan petunjuk penggunaan media, (20) jumlah tampilan sesuai dengan waktu yang disediakan, dan (21) membantu pemahaman materi. Berdasarkan penilaian ahli media, pernyataan nomor 3, 15, 16 dan 17 mendapatkan skor penilaian 5 sedangkan pernyataan nomor 1,2 , $4,5,6,7,8,9,10,11,12,13,14,18,19,20$ dan 21 memperoleh skor 4 . Rata-rata penilaian ahli media terhadap aspek media adalah 4 yang termasuk dalam kategori "baik".

Persentase penilaian ahli media pada aspek media tampak pada Tabel 3 berikut ini:

Tabel 3. Persentase Penilaian Aspek Media oleh Ahli Media

\begin{tabular}{ccc}
\hline Kriteria & Frekuensi & \% \\
\hline Sangat Baik & 4 & $18,18 \%$ \\
Baik & 18 & $81,81 \%$ \\
Cukup Baik & 0 & $0 \%$ \\
Kurang Baik & 0 & $0 \%$ \\
Sangat Kurang Baik & 0 & $0 \%$ \\
Jumlah & $\mathbf{2 2}$ & $\mathbf{1 0 0 \%}$ \\
\hline
\end{tabular}

Berdasarkan Tabel 3, ada empat pernyataan yang termasuk dalam kategori "sangat baik" dan ada 18 pernyataan yang termasuk dalam kategori "baik". Tidak ada pernyataan yang termasuk dalam katergori "cukup baik", "kurang baik" maupun "sangat kurang baik".

Hasil akhir kualitas media pembelajaran berdasarakan review ahli materi dan pembelajaran terhadap aspek materi dan pembelajaran dapat dilihat pada Tabel 4 berikut: 
Tabel 4. Hasil Akhir Penilaian Ahli Materi dan Pembelajaran

\begin{tabular}{ccc}
\hline Aspek & Rata-rata & Kategori \\
\hline Materi & 4,42 & Sangat Baik \\
Pembelajaran & 4,53 & Sangat Baik \\
Total & \multicolumn{2}{c}{8,95} \\
Rata-rata & \multicolumn{2}{c}{$\mathbf{4 , 4 8}$} \\
Kualitas akhir & Sangat Baik \\
\hline
\end{tabular}

Berdasarkan Tabel 4, penilaian ahli materi dan pembelajaran terhadap aspek materi dan aspek pembelajaran tersebut 4, 21 yaitu 4,42 pada aspek materi dan 4,53 pada aspek pembelajaran sehingga rata-rata penilain menjadi 4,48. Angka 4,48 menunjukkan bahwa kualitas media pembelajaran setelah dilakukan validasi pada ahli materi memiliki kualitas yang sangat baik. Meskipun data hasil uji coba menunjukkan nilai sangat baik, peningkatan kualitas produk media pembelajaran terus dilakukan dengan berdasar pada komentar dan saran pada valiadasi dan uji coba selanjutnya.

Selain penilaian dari para ahli, para siswa juga memberikan penilaia terhadap media yang dikembangkan pada aspek materi, pembelajaran dan media. Pada aspek materi, para siswa membeikan penilaian terhadap 9 indikator penilaian yaitu: (1) ketepatan materi, (2) pentingnya materi, (3) kemenarikan materi, (4) materinya mudah dipahami, (5) materinya bermanfaat untuk kehidupan siswa, (6) kesesuaian materi dengan situasi siswa, (7) bahasa yang digunakn mudah dipahami, (8) kesesuain materi dengan soal, dan (9) tingkat kesulitan butir soal.

Pada aspek pembelajaran, para siswa memberikan penilaian terhadap 10 indikator penilaian, yaitu: (1) kejelasan rmusan kompetensi dasar, (2) kejelasan petunjuk belajar, (3) penyampaian materi runtut, (4) penyampaian materi menarik, (5) pemberian contoh-contoh dalam penyajian, (6) pemberian animasi, suara, dna video sebagai bahan enarik perhatian siswa, (7) kegiatan belajar dapat memotivasi siswa, (8) pemberian soal latihan untuk pemahaman materi, (9) pemberian soal evaluasi untuk mengukur kemampuan siswa, dan (10) respon terhadap jawaban siswa.

Aspek yang juga dinilai oleh siswa adalah aspek media. Ada 12 indikator penilaian yang dinilai, yaitu: (1) penggunaan jenis dan ukuran huruf, (2) keterbacaan teks, (3) kualitas tampilan gambar, (4) kualitas tampilan video, (5) kejelasan suara, (6) kualitas musik, (7) komposisi dan kobinasu penggunaan warna, (8) kemudahan dalam penggunaan media, (9) pemberian respon yang tepat, (10) kejalasan petunjuk penggunaan media, (11) membantu pemahaman materi, dan (12) membangkitkan motivasi siswa.

Pada saat uji coba satu-satu yang diikuti oleh 3 orang siswa, diperoleh rata-rata penilaian pada aspek materi, pembelajaran dan media. Pada sapek materi, rata-rata penilaian sebesar 3,93 yang termasuk dalam kategori "baik". Pernyataan nomor 2, 4, dan 5 termasuk dalam kategori "sangat baik" dan pernyataan nomor 1 , 3, 7, 8 dan 9 termasuk dalam kategori "baik". Ada 1 pernyataan yang termasuk dalam kategori "cukup baik yaitu pernyatan nomor 6. Pada aspek pembelajaran, rata-rata penilaian yang diperoleh adalah 3,83 dan termasuk dalam kategori "baik". Pernyataan nomor 4 dan 9 termasuk dalam kategori "sangat baik", pernyataan nomor 1, 3, 5, 6, 7 dan 8 termasuk dalam kategori "baik". Ada dua pernyataan yang termasuk dalam kategori "cukup baik" yaitu pernyataan nomor 2 dan 10. Pada aspek media, rata-rata penilaian yang diperoleh adalah 3,86 yang termasuk dalam kategori "baik". Pernyataan nomor 8 dan 11 termasuk dalam kategori "baik", pernyataan nomor $1,2,3,4,5,6,9$ dan 12 termasuk dalam kategori "baik" sedangkan pernyataan nomor 10 termasuk dalam kategroti "cukup baik".

Perbandingan skor rata-rata aspek materi, pembelajaran dan media pada uji coba satu-satu tampak pada Gambar 8 berikut ini:

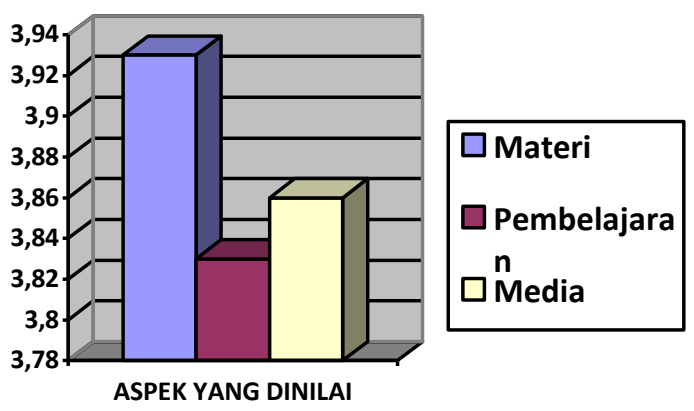

Gambar 8. Diagram Perbandingan Skor Ratarata yang Diperoleh pada Uji Coba Satu-satu

Pada saat uji coba kelompok kecil yang diikuti oleh 12 siswa, juga diperoleh hasil penilaian siswa dari aspek materi, pembelajaran dan media. Pada aspek materi, rata-rata penilaian yang diperoleh adalah 4,11 yang termasuk dalam kategori "baik". Pernyataan nomor 2, 5 dan 6 termasuk dalam kategori "sangat baik" sedangkan pernyataan nomor $1,3,4,7,8$ dan 9 termasuk dalam kategori "baik". Pada aspek pembelajaran, rata-rata penilaian yang diperoleh 
adalah 3,98 yang termasuk dalam kategori "baik". Pernyataan nomor 4 dan 5 termasuk dalam kategori "sangat baik" sedangkan pernyataan nomor 1, 2, 3, 6, 7, 8, 9 dan 10 termasuk dalam kategori "baik". Pada aspek media, ratarata penilaian yang diperoleh adalah adalah 3,85 yang termasuk dalam kategori "baik". Semua pernyataan dari nomor 1 sampai dengan nomor 12 mendapat nilai diantara 3,40 sampai 4,21 sehingga termasuk dalam kategori "baik".

Perbandingan skor rata-rata aspek materi, pembelajaran dan media pada uji coba kelompok kecil, tampak pada Gambar 9 berikut:

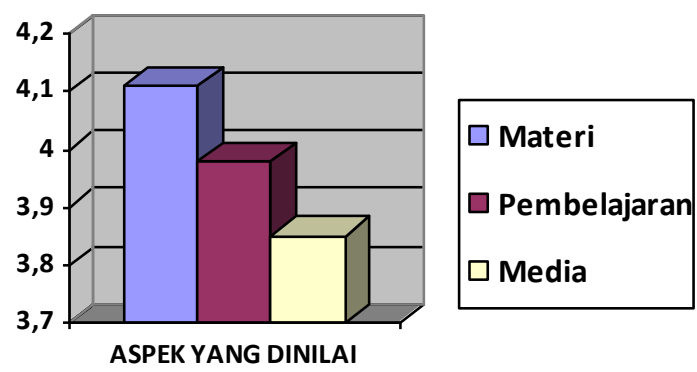

Gambar 9. Diagram Perbandingan Skor Ratarata yang Diperoleh pada Uji Coba Kelompok Kecil

Pada saat uji coba lapangan yang diikuti oleh 30 orang siswa, juga diperoleh rata-rata penilaian dari aspek aspek materi, pembelajaran dan media. Pada aspek materi, rata-rata penilaian yang diperoleh adalah 4,20 yang termasuk dalam kategori "baik". Pernyataan nomor 2, 5 dan 8 termasuk dalam kategori "sangat baik" sedangkan peryataan nomor 1, 3, 4, 6, 7 dan 9 termasuk dalam kategori "baik". Pada aspek pembelajaran, rata-rata penilaian yang diperoleh adalah 4,28 yang termasuk dalam kategori "sangat baik". Pernyataan nomor 4, 5, 6, 7, 8, 9 dan 10 termasuk dalam kategroi "sangat baik" sedangkan pernyataan nomor 1, 2, dan 3 termasuk dalam kategori "baik". Pada aspek media, rata-rata penilaian yang diperoleh adalah 4,10 yang termasuk dalam kategroi "baik". Pernyataan nomor 2, 8, 9, 11 dan 12 termasuk dalam kategori "sangat baik" sedangkan peryataan nomor 1, 3, 4, 5, 6, 7 dan 9 termasuk dalam kategori "baik".

Perbandingan skor rata-rata aspek materi, pembelajaran dan media pada saat uji coba lapangan yang tampak pada Gambar 10 berikut ini:

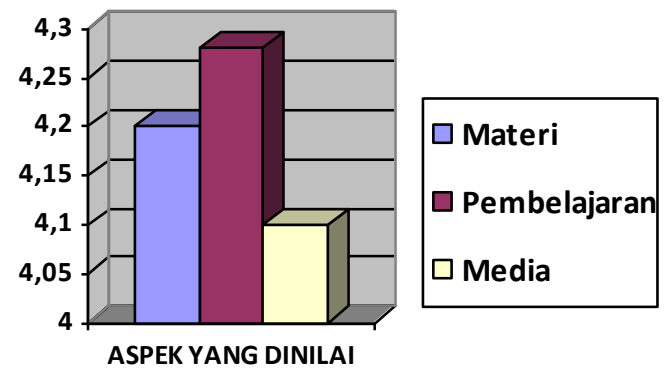

Gambar 10. Diagram Perbandingan Skor

Rata-rata yang Diperoleh pada Uji Coba Lapangan

Rangkuman hasil analisis data review dari ahli materi dan pembelajaran, ahli media dan data uji coba dapat dilihat pada Tabel 5 berikut:

Tabel 5. Rangkuman Hasil Analisis Data

\begin{tabular}{cccc}
\hline Evaluator & Aspek & $\begin{array}{c}\text { Rata- } \\
\text { rata } \\
\text { Skor }\end{array}$ & Kategori \\
\hline Ahli materi & Materi & 4,42 & $\begin{array}{c}\text { Sangat } \\
\text { Baik }\end{array}$ \\
dan & Pembelajaran & 4,53 & $\begin{array}{c}\text { Sangat } \\
\text { Baik }\end{array}$ \\
pembelajaran & Rata-rata & 4,48 & Sangat \\
Ahli Media & Media & 4 & Baik \\
Siswa & Materi & 3,93 & Baik \\
(Uji Coba & Pembelajaran & 3.83 & Baik \\
Satu-satu) & Media & 3,86 & Baik \\
Siswa & Rata-rata & 3,87 & Baik \\
(Uji coba & Materi & 4,11 & Baik \\
Kelompok & Melajaran & 3.98 & Baik \\
kecil) & Rata-rata & 3,85 & Baik \\
& Materi & 4,98 & Baik \\
Siswa & Pembelajaran & 4,28 & Baik \\
(Uji Coba & Sangat \\
Lapangan) & Media & 4,10 & Baik \\
\cline { 2 - 4 } & Rata-rata & 4,19 & Baik \\
\hline
\end{tabular}

Berdasarkan pada rangkuman hasil analisis data pada Tabel 1, terlihat bahwa ahli materi dan pembelajaran rata-rata memberikan rata-rata 4,48 dengan kategori sangat baik untuk aspek pembelajaran dan materi. Ahli media memberikan penilaian 4 dengan kategori baik. Pada uji coba satu-satu rata-rata skor penilaian siswa 3,87 yang termasuk dalam kategori baik dengan rata-rata skor tertinggi pada aspek materi, yaitu 3,93. Pada uji coba kelompok kecil rata-rata skor penilaian siswa adalah 3,98. Rata-rata tertinggi pada uji coba kelompok kecil ada pada aspek materi sebesar 4,11. Pada uji coba lapangan, rata-rata penilaian siswa adalah 4,19 yang 
termasuk dalam kategori "baik". Rata-rata tersebut merupakan rata-rata tertinggi dari semua uji coba yang dilakukan dimana semua aspek penilaian memperoleh skor tanggapan di atas 4,00 .

Berdasarkan hasil analisis data, kelayakan media pembelajaran dilihat dari rata-rata penilaian masuk dalam kategori "baik" di semua tahapan uji coba. Nilai kelayakan yang telah ditetapkan dalam penelitian ini adalah "Cukup Baik", maka produk media pembelajaran ini telah memiliki kelayakan yang ditetapkan.

Selain mendapatkan penilaian dari ahli materi dan pembelajaran, ahli media, siswa saat uji coba satu-satu, siswa saat uji coba kelompok kecil dan uji coba lapangan, juga didapatkan komentar dan saran perbaikan yang segera ditindaklajuti. Komentar dan saran perbaikan dari ahli materi dan pembelajaran antara lain: (1) tombol "NEXT" dirubah menjadi "START"; (2) tombol "NEXT" dibuat lebih terlihat, misal diberi warna yang terang pada kotakannya; (3) jenis huruf untuk Judul dibuat yang lebih menarik; (4) hilangkan tulisan nomor slide; (5) Tulisan "EXIT" diletakkan dipojok kiri bawah; (6) perlu diberi gambar di tengah, agar slide nya tidak kosong; (7) posisi penyajian materi dirubah; (8) tulisan click the "VIDEO" dibuat sama dengan icon untuk memainkan video; (9) tiap video agar diberi transkrip ekspresi yang digunakan, lalu dibold ekspresinya; (10) tombol sound diperjelas dan perintahnya dirubah; (11) tulisan "Check Answer” dibuat lebih jelas

Komentar dan saran perbaikan dari ahli media adalah sebagai berikut: (1) slide judul perlu dilengkapi dengan identitas (Prodi/ NIM); (2) perlu diberi konfirmasi tombol "EXIT" jika keluar dari program; (3) struktur penyajian materi; (4) menu yang setara dibuat dengan huruf yang sama yaitu pada judul; (5) diberi tombol reset pada semua slide yang menampilkan latihan yang disertai jawaban; (6) pemberian video pada soal-soal evaluasi; (7) evaluation summary perlu direvisi; (8) volume suara sebaiknya sama antar video/sound; (9) gambargambar yang relevan perlu dimasukkan ke pertanyaan nomor 7 sampai dengan nomor 15 ; (10) profile perlu dilengkapi.

Komentar dan saran perbaikan setelah dilakukan uji coba satu-satu, uji coba kelompok kecil dan uji coba lapangan adalah sebagai berikut: (1) CD pembelajaran sangat membantu siswa karena disajikan dengan tampilan yang menarik, penyampaian materi lengkap dan mudah dipahami; (2) Lebih baik lagi bila diberi petunjuk penggunaan mana yang penting dan mana yang seharusnya dipilih lebih dahulu; (3) kombinasi warna bisa diatur lagi agar lebih menarik; (4) diberi gambar-gambar agar lebih menarik; (5) tampilan gambar diperbanyak dan diberi animasi-animasi agar lebih semangat, dialognya diperbanyak; (6) tampilan video kurang besar; (7) video di materi 2 terpotong, mohon di-upgrade lagi; (8) menampilkan video kartun yang berisi tentang materi, diberi gambar karikatur yang menarik agar pembelajaran terlihat santai; (9) penambahan gambar pada slideslide materi.

Komentar dan saran perbaikan dari ahli materi dan pembelajaran, ahli media dan dari siswa tersebut ditindaklanjuti dengan mengadakan revisi media pembelajaran sesuai dengan saran yang diberikan. Hal ini dilakukan untuk meningkatkan kualitas media pembelajaran.

Contoh perubahan yang dilakukan berdasarkan saran dan komentar dari para ahli dan siswa tampak pada Gambar 11 sampai 13 berikut:

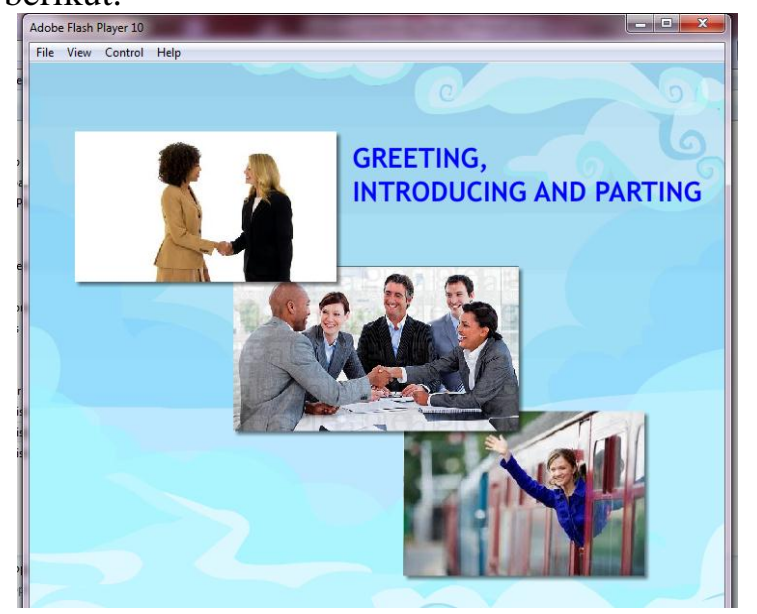

Gambar 11. Tambahan Slide Slide Materi 1

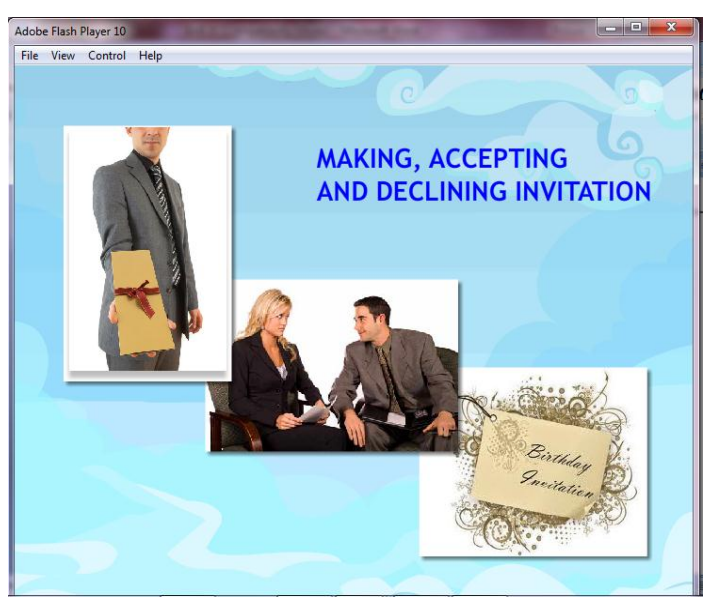

Gambar 12. Tambahan Slide Materi 2 


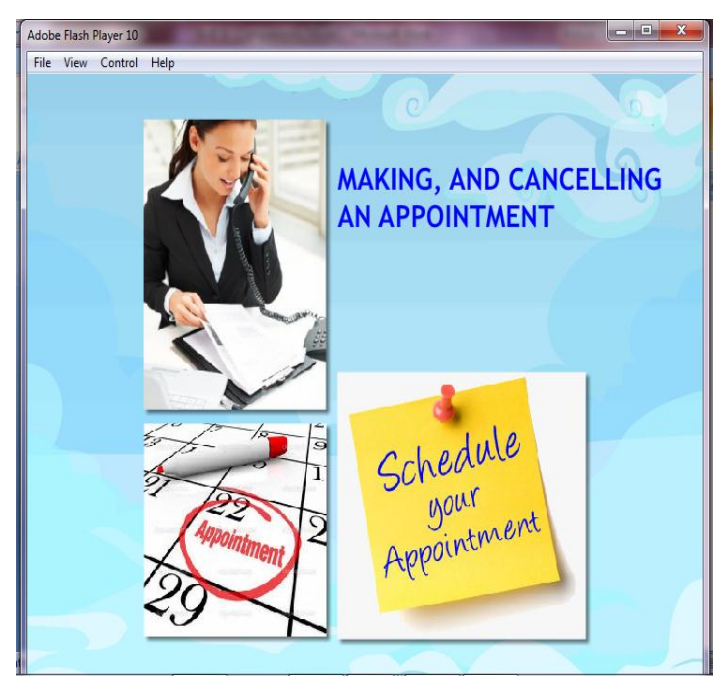

Gambar 13. Tambahan Slide pada Materi 3

Selanjutnya, untuk mengetahui dampak penggunaan media pembelajaran terhadap pencapaian hasil belajar siswa maka dilakukan tes awal (pretest) dan tes akhir (posttest). Pretest dikerjakan oleh siswa sebelum mencoba media pembelajaran sedangkan posttest dikerjakan oleh siswa setelah mencoba media pembelajaran. Nilai hasil pretest dan posttest menunjukkan adanya peningkatan prestasi siswa dalam penguasaan materi menyimak setelah para siswa menggunakan media pembelajaran berbasis komputer yang didesain dalam penelitian. Peningkatan itu dapat dilihat dari adanya peningkatan rata-rata nilai pretest dari 6,75 menjadi 7,65 pada posttest. Berdasarkan kriteria ketuntasan minimal sekolah yaitu 7,00 dapat dilihat adanya peningkatan jumlah siswa yang mencapai ketuntasan minimal. Pada saat pretest, jumlah siswa yang tuntas ada 16 siswa (53.3\%) dan yang tidak tuntas ada 14 siswa $(46,7 \%)$. Setelah dilakukan post-test, jumlah siswa yang tuntas meningkat dari 16 siswa $(53,3 \%)$ menjadi 23 siswa $(76,6 \%)$ dan terjadi penurunan jumlah siswa yang tidak tuntas dari 14 siswa $(46,67 \%)$ menjadi 7 siswa $(33,4 \%)$. Perhitungan data tersebut menunjukkan bahwa media pembelajaran komputer memberikan dampak positif terhadap prestasi belajar siswa dalam penguasaan keterampilan menyimak. Sehingga dapat dinyatakan juga bahwa media pembelajaran ini efektif digunakan dalam pembelajaran menyimak bagi siswa SMA kelas X.

Selain itu, berdasarkan komentar dari ahli materi dan pembelajaran, ahli media serta siswa di semua tahapan uji coba dapat disimpulkan bahwa siswa sangat senang menggunakan media pembelajaran ini karena pembelajaran bahasa Inggris menjadi lebih menarik dengan adanya video, gambar dan tampilan yang menarik. Siswa juga lebih termotivasi untuk belajar bahasa Inggris karena adanya latihan-latihan soal dengan feedback langsung sehingga siswa bisa mengetahui hasil latihan mereka.

Media pembelajaran untuk keterampilan menyimak ini berbentuk program/software yang memiliki beberapa kelebihan antara lain: (1) Program ini dapat langsung digunakan pada komputer tanpa harus menginstal program lain sehingga memudahkan siswa untuk menjalankan media pembelajaran ini tanpa harus menginstal flash player terlebih dahulu; (2) program ini memiliki tombol-tombol navigasi yang interaktif dan konsisten untuk memudahkan siswa menjelajah setiap slide dengan mudah; (3) program ini dikemas dalam bentuk $\mathrm{CD}$ dengan ukuran file cukup kecil namun memuat materi yang cukup padat; (4) program ini dapat dipergunakan untuk pembelajaran mandiri maupun klasikal di dalam kelas. Dalam pembelajaran mandiri, siswa bisa belajar bahasa Inggris sesuai dengan kecepatan dan kemampuan masing-masing siswa di sekolah maupun di rumah. Sedangkan untuk pembelajaran klasikal, penggunaan media ini bisa dilakukan oleh guru dengan menggunakan LCD projector dan speaker; (5) program ini merupakan program pembelajaran bahasa Inggris yang interaktif diliengkapi dengan video, gambar dan tampilan yang menarik sehingga tidak membuat siswa bosan untuk belajar bahasa Inggris terutama keterampilan menyimak.

Namun, media pembelajaran ini mempunyai beberapa keterbatasan, yaitu: (1) pengembangan produk media pembelajaran ini meskipun telah melalui serangkaian validasi dan uji coba namun produk ini masih belum sempurna ditinjau dari jumlah dan variasi materi maupun soal yang disajikan; (2) media pembelajaran yang dikembangkan melalui penelitian ini belum dapat digunakan untuk memfasilitasi siswa dalam pembelajaran bahasa Inggris yang mencakup empat keterampilan berbahasa yang terdiri atas menyimak, berbicara, membaca dan menulis. Media pembelajaran ini dapat digunakan untuk memfasilitasi siswa dalam pembelajaran bahasa Inggris khususnya pada keterampilan menyimak; (3) Dalam suara yang disajikan, ada beberapa ucapan-ucapan lisan dalam materi menyimak yang diucapkan oleh pembicara Indonesia bukan native speaker. Namun, suara yang disajikan sudah cukup baik sebagai model bagi siswa SMA kelas X; (4) Jumlah komputer dan headphone yang dimiliki oleh sekolah dimana uji coba dilaksanakan masih terbatas, sehingga 
pada saat uji coba lapangan (field trial) harus dilakukan secara bertahap.

\section{SIMPULAN}

Berdasarkan hasil analisis data yang dimulai dari review ahli media, ahli materi dan pembelajaran, uji coba satu-satu, uji coba kelompok kecil, dan uji coba lapangan maka dapat disimpulkan bahwa pengembangan media pembelajaran bahasa Inggris berbasis komputer untuk keterampilan menyimak SMA kelas $\mathrm{X}$ harus dilakukan melalui prosedur pengembangan media yang benar dan sesuai dengan kebutuhan siswa. Pengembangan media, dilakukan secara bertahap. Ada 4 tahapan yang harus dilalui yaitu: (1) penelitian pendahuluan, (2) perencanaan pengembangan media, (3) produksi media, dan (4) evaluasi media dan revisi.

Hasil penelitian menunjukkan bahwa kualitas media pembelajaran hasil pengembangan ditinjau dari aspek materi dinilai baik dengan rata-rata skor sebesar 4,20 ditinjau dari aspek pembelajaran dinilai sangat baik dengan ratarata skor sebesar 4,28; dan ditinjau dari aspek media dinilai baik dengan rata-rata skor 4,10. Secara keseluruhan, kualitas media pembelajaran yang dikembangkan dinilai baik dengan ratarata skor sebesar 4,19 .

\section{DAFTAR PUSTAKA}

Arsyad, A. (2010). Media pembelajaran. Jakarta: PT. Raja Grafindo Persada.

Borg, W.R., Gall, M. D., Gall, J. P. (1983). Educational reseach: An introduction. Boston: Pearson Education, Inc.
Brown, H. D. (2001). Teaching by principles: An interactive approach to language pedagogy. New York: Longman Incorporation.

Dick ,W., Carey, L.\& Carey,J.O. (2005). The systematic design of instruction $\left(6^{\text {th }}\right.$ Edition). Boston: Pearson.

Feez, S., \& Joyce, H. (2002). Text-based syllabus design. Cambrige: Cambridge University Press.

Lee, W. W. \& Owens, D. L. (2004). Multimedia based-intructional design: computerbased training, web-based training, distance broadcast training, performancebased solutions-2nd ed. New York: John Wiley \& Sons, Inc.

Newby, T.J., et al. (2011). Educational technology for teaching and learning (fourth edition). Boston: Pearson Education, Inc.

Pujiriyanto. (2005). Desain grafis komputer. Yogyakarta: Penerbit Andi.

Puspito, H. A. (2010). Having fun with adobe flash CS4 professional.Yogyakarta: Scripta Media Creative.

Situmorang, S. H. (2010). Analisis data: untuk riset manajemen dan bisnis. Medan: USU Press.

Sukardjo. (2008). Evaluasi pembelajaran. Yogyakarta: Program Pascasarjana Universitas Negeri Yogyakarta. 